\title{
The Social and Economic Exchange Relationships in the Context of Organizational Commitment
}

\author{
Burcu AYDIN-KÜÇÜK ${ }^{1}$
}

\section{Abstract}

Social Exchange Theory (SET) is one of the fundamental theories that has presented theoretical viewpoint in the several disciplines such as anthropology and social psychology. It is known that the theory roots which early conceptualized by Thibault \& Kelley (1959), Homans (1961), Blau (1964) and Emerson $(1962,1972)$ base on back to the 1920s (Malinowski, 1922). The main idea of exchange theory is to a set of interactions that leads to obligations (Emerson, 1976). At this point, the findings from social exchange studies have many contributions and benefits in order to understand workplace behaviors (Cropanzano \& Mitchell, 2005). SET has been one of the main theories that provide a wide comprehension upon exchange dynamics at both the interpersonal and organizational level. Divided into two categories, namely social (SE) and economic (EE), exchange relationships have seen to be related to many organizational outcomes, including organizational commitment (OC), which can be defined as employees' attitude towards their organization. The present study purposes to determine the correlation between SET and subdimensions of OC (affective commitment and continuance commitment). Data of the study have been obtained from 186 employees who work in private sector in Turkey and analyzed through Statistical Package for the Social Sciences. Results indicated that Social Exchange is positively related with affective commitment and continuance commitment, Economic Exchange was found to be negatively related with affective commitment and positively correlated with continuance commitment.

Key Words: Social exchange, Economic exchange, Affective commitment, Continuous commitment

\section{Örgütsel Bağlılık Kapsamında Sosyal ve Ekonomik Değişim İlişkileri}

\section{Öz}

Sosyal Değişim Teorisi (SDT), antropoloji, sosyal psikoloji ve sosyoloji gibi birçok disipline teorik bakış açısı sunan temel teorilerden biridir. İlk olarak Thibault ve Kelley (1959), Homans (1961), Blau (1964) ve Emerson $(1962,1972)$ tarafından kavramsallaştırılan teorinin köklerinin 1920'lere dayandığı bilinmektedir (Malinowski, 1922). Değişim teorisinin ana fikri, zorunluluk oluşturan bir dizi etkileşimdir (Emerson, 1976). Bu noktada sosyal değişim çalşsmalarından elde edilen bulgular işyeri davranışlarını anlamak için pek çok katkı ve faydalar sunmaktadır (Cropanzano ve Mitchell, 2005). SDT, hem kişilerarası düzeyde hem de örgütsel düzeyde değişim dinamikleri üzerine geniş bir kavrayış sağlayan ana teorilerden biri olmuştur. Sosyal değişim ve ekonomik değişim olmak üzere iki alt boyuta ayrılan değişim ilişkilerinin çalışanların kendi örgütlerine karşı tutumu olarak tanımlanabilecek olan örgütsel bağlllık (ÖB) dahil olmak üzere çeşitli örgütsel sonuçlarla ilişsili olduğu görülmektedir. Bu çalışma, SDT ile ÖB alt boyutları arasındaki ilişkiyi belirtmeyi amaçlamaktadır (duygusal bağılılk ve devam bağlılığı). Çalışmanın verileri, Türkiye'de özel sektörde çalışan 186 çalışandan elde edilmiş ve Sosyal Bilimler için İstatistik Paketi ile analiz edilmiştir. Sonuçlar, Sosyal değişimin duygusal bağlllık ve devam bağlllı̆̆ı ile pozitif ilişkili olduğunu; ekonomik değişimin duygusal bağlllık ile negatif ilişkili olduğunu ve devam bağlllığı ile pozitif ilişkili içinde olduğunu göstermiştir.

Key Words: Sosyal değişim, Ekonomik değişim, Duygusal bağlllık, Devam bağgllığı

\section{Atıf İçin / Please Cite As:}

Aydın-Küçük, B. (2020). The social and economic exchange relationships in the context of organizational commitment. Manas Sosyal Arasstrmalar Dergisi, 9(4), 2337-2348.

Geliş Tarihi / Received Date: 31.10 .2019

Kabul Tarihi / Accepted Date: 25.06.2020

\footnotetext{
${ }^{1}$ Dr. Öğr. Üyesi - İstanbul Aydın Üniversitesi İktisadi ve İdari Bilimler Fakültesi, burcuaydinkucuk@gmail.com ORCID: 0000-0001-9081-2536.
} 


\section{Introduction}

The concept of organizational commitment has been one of the most widely researched topics in the organizational behavior literature since 1980s (Meyer, \& Allen, 1980). The reason for this is that the concept is still one of the most important issues of modern organizations in many countries due to its contribution to organizational effectiveness and efficiency (Angle, \& Perry, 1981; Reichers, 1985; Steers, 1997; Markovits, Davis, \& Dick, 2007; Cohen, 2014; Anttila, 2015; Radosavljevic, Cilerdzic, \& Dragic, 2017; Dabir, \& Azarpira, 2017; Annakili, \& Jayam, 2019). Mainly, organizational commitment has become a highly valued concept from past to today because its impact is felt by organization members and organization itself in terms of many desirable outcomes (Buchanan, 1974; Angle, \& Perry, 1983; Top, Akdere, \& Tarcan, 2015). Especially, in competitive business world, employee's commitment has become the most important needed in order to show superior performance at overall organizational level (Eaton, 2003; Berberoğlu, 2015). Therefore, many researchers and social scientists have studied organizational commitment and its positive impacts on individual and organization (McGee, \& Ford, 1987; Sager, \& Johnston, 1989; Randall, Fedor, \& Longenecker, 1990; Cheng, Jiang, \& Riley, 2003; Wasti, 2005; Hanaysha, 2016).

Organizational commitment requires intense dedication, and it is more strong than employee's best intentions, willpower, or circumstances. It is a belief of individual about organizational values, aims and the will of achievement of that aims. If there is no commitment, influences of employees on their work will be minimal. As a result, employees may lose their passion, impact, and opportunities in the work process (Maxwell, 1999). Commitment to organization refers to degree of the strength of one's identification with organization. Additionally, it relates one's involvement in a present organization (Lyons, Duxbury, \& Higgins, 2006). There are many conceptualizations in the related literature and many measures have been proposed by the researchers but Meyer and Allen (1991) have discussed organizational commitment in great detail. Just like other models, this model also explains organizational commitment as a psychological state and this style of commitment has three different components that affect how employee feels about the organization that $\mathrm{s} /$ he works for. These components are classified as affective, continuance and normative (Meyer, \& Allen, 1991).

As a first dimension, affective commitment is the emotional bonding of employees towards their job. Such commitment involves in the degree of employee's emotional attachment with their organization. At the same time, The degree of identification and involvement with organization is an indicator for affective commitment style. If employees in the organization feel strong commitment in this dimension, they are willing to continue employment with the current organization. As a second dimension of the concept, continuance commitment is associated with the fear of loss of one's current job. It refers to the awareness of employees about their costs they will incur when they leave the current organization. Athe same time, such commitment style is related with what costs would occur regarding the result of resignation of employees. As a third dimension, normative commitment means the sense of obligation to stay in the current job. It reflects a feeling of obligation to continue employment in the current organizations. In other words, keeping up the membership of the organization is understood as responsibility (Allen, \& Meyer, 1991). In brief, each employee can experience such psychological states and they can feel commitment towards organization in the varying levels because of different reasons. Sometimes this reason of employees can be sourced from either a strong need ora strong obligation in point of remain in the organization. But, others may want to continue in the organization because they fully desire to remain in the organization without need or obligation (Allen, \& Meyer. 1991).

Hereby, organizational commitment has been still increasingly studied in the relevant literature since its possible individual and organizational outcomes are considered crucial for organizations. As it is expected, employees with higher commitment tend to work efficiently (Angle, \& Perry, 1981). Therefore, as well as its outcomes, the reasons for organizational commitment are still discussed in detail by many researchers. In the context of present study, it is thought that the quality of reciprocity relationship between employees and organization can help organizational authorities to increase employees' commitment level. In this respect, it can be considered that social and economic change relationship is the antecedent of organizational commitment.

Social exchange is a fundamental construct that can be found in every aspect of life, directing interdependent interactions at both personal and group level (Cropanzano, \& Mitchell, 2005). Social exchange can be defined as deliberate actions that are performed by individuals or groups with the 
expectation that other party will act in a similar fashion (Blau, 1964). In social interactions, it is argued that individuals are inclined to feel an obligation to reciprocate in a manner that they were confronted with (Song, Tsui, \& Law, 2009).

Exchange relationships have an extensive theoretical background in the relevant literature. Blau (1964), who developed social exchange theory, is arguably the most influential figure in exchange relationships. According to Blau (1964), individuals are driven for finding a balance between what they gave and what they received. In his social exchange theory, he argues that individuals' perceived incongruence between what was given and what was gathered will result in efforts to eliminate this discrepancy by their actions (Molm, 2003). Thus, individuals who receive favors will have a tendency to reciprocate with behaviors that are favorable to other party, and vice versa. From this point of view, the relationship between employees and their organizations can be defined as an exchange that has both social and economic components. As a matter of fact, exchange relationships within organization are determined by voluntary actions that are performed with the expectation that those actions will be returned in a similar way (Köksal, 2012).

Since some exchanges are based merely on economic transactions, while others generate socioemotional responses such as gratitude, trust, obligation and so forth, a distinction has been made economic and social exchange in the relevant literature (Hackett, Farh, Song, \& Lapierre, 2003). Transactions that include relatively short-term and financially oriented relationships are defined as economic exchange. In an economic exchange, interactions are based on the exchange of commodities and services that have values that are distinct from the values that interacting parties are attributing to them. Since the main motivation is to gain advantage economically, employees expects a set of financial outcomes in exchange when they discharge their job duties (Shore, Bommer, Rao, \& Seo, 2009). For this reason, both the resources that are exchanged and the expected actions from each other are identified in economic exchanges (Podsakoff, MacKenzie, Paine, \& Bachrach, 2000). Moreover, it is not expected to entail investment by either the employee or the organization in such relationships because of impersonal exchange (Shore et al., 2009).

Conversely, social exchange is based on different, rather more complex obligations. In social exchange, individuals consider not only increasing their concrete gatherings, but also developing a satisfactory relationship, as well. Interactions are not all about what parties have received in a short period of time (Song et al., 2009). Apart from that, social exchange relationships are determined by some unwritten rules, which are based on common sense (Ertürk, 2014). Another fundamental distinction between social and economic exchange is that trust is one of the key components of interactions in social exchange relationships (Cole, Schaninger, \& Harris, 2002). At the same time, Blau (1964) emphasized that obligations are indefinite in social exchange relationships because the reason for being a favor to another ones is to expectation of some future return. In such circumstance, when and how to return of favor is often ambiguous. Therefore, relationships in such exchange base on trustworthiness among parties.

Studies have shown significant relationships between social exchange and commitment (Shore, \& Wayne, 1993; Hom et. al, 2009). To be more specific, social exchange has positive associations with affective commitment (Hom et. al., 2009). Regarding the affective commitment, in case employees develop relationship based on social reciprocity with their organizations, they are likely to have attachment and identification with their organizations. For this reason, social exchange element would motivate them to feel more involvement and embeddedness towards the organization that they are working for. As to the continuous commitment, individuals may think that staying in the present organization is more beneficial for them in place of gaining in a new role in other organization. Here, this loss cannot be considered only economically, it also has a social dimension because individuals don't want to lose friendships or allies in their life. Therefore, continuous commitment is expected to be related to social change.

As mentioned before, economic exchange emphasizes the tangible side of organizational commitment such as financial outcomes. For this reason, because affective commitment is the emotional bonding of an employee towards his/her job, it cannot be explained as an economic exchange. Then, it is expected that affective commitment has negative associations with economic exchanges. Yet, continuance commitment is associated with a balancing of the costs of leaving an organization and the benefits of staying in organization; therefore this dimension is expected to be positively related to economic change. 
Hence, the main purpose of this study is to reveal existing knowledge about social and economic exchange, and the relations of two components of organizational commitment, and to examine the direction and degree of the relationship among concepts. The main idea of relationships in both private and institutional life is to get the return from other parties. At this point, it is realized that the central norm underlying exchange relationship at organizations is reciprocity as social or economic outputs (Zhu, 2012). On the other side, employee perceptions towards the exchange relationship within their organization are important determinants for the organizational antecedents and outcomes. In addition, exchange relationships underlines that employees respond to their organization differently as far as the treatment they perceive. Eventually, these treatments may lead either a social exchange relationship such as trust in relatively long-term or an economic exchange relationship such as highly circumscribed in short-term (Shore et.al., 2006; Song, Tsui, \& Law, 2006). For this reason, understanding the effect of the social and economic exchange relationship on organizational commitment will be important for employees.

In sum, the objective of the current research is to reveal the impact of individuals' reciprocity relationship with their organization on their organizational commitment level in Turkish private sector context.

\section{Method}

\section{Hypotheses}

The purpose in this study is to conduct a survey with employees of private sector in Turkey and investigate the relationships among economic exchange, social exchange and organizational commitment. The hypothetical propositions of this study, which are detailed in the literature review section, are as follows:

H1: Social exchange is related with sub-dimensions of organizational commitment.

H1.1: Social exchange is positively related with affective commitment.

H1.2: Social exchange is positively related with continuance commitment.

$\mathrm{H} 2$ : Economic exchange is related with sub-dimensions of organizational commitment.

H2.1: Economic exchange is negatively related with affective commitment.

H2.2: Economic exchange is positively related with continuance commitment.

\section{Sample and Data Collection}

In this study, a single source data collection method (e.g. employees) and a single-method study (e.g., questionnaire) have been used to collect the data. A cross-sectional field survey has been selected because of the nature of the research questions and hypotheses. The surveys, which include social exchange, economic exchange, affective commitment and continuance commitment questionnaires as the questionnaires of independent and dependent variables, have been answered by the employees. After collecting the data, the survey questionnaires have been matched to prepare for the statistical analysis.

The data for this study have been acquired from a sample of 186 participants from various private sectors in Turkey. Considering that the importance of employees' emotions and attitudes, it is important to know the reasons for their attitudes. Within this framework, the research has focused on determining organizational antecedents and outcomes by seeking reasons for employee emotions and attitudes. Therefore, the sample of the study involves employees who had been employed in various organizations in private sector companies located in İstanbul. The participants did not have managerial position because it was thought that one of the reason for their commitment to organization can be sourced of their manager. Therefore, managers were not included in the sample group. As a data collection method, online and paper-based surveys were used in the study. Of the 198 responses, 12 surveys were disregarded because of missing data or suspect responses. Afterwards, of remaining 186 surveys, 144 were obtained as online and 54 surveys were obtained as paperbased. Thus, data obtained from 186 employees were analyzed through the Statistical Package for the Social Sciences and hypotheses were tested through statistical analyses.

\section{Demographic Characteristics}

In terms of demographic findings, $52 \%$ of respondents were females, and the remaining $48 \%$ were males. The respondents were between 21 and 51 years of age. The total tenure of the respondents was 6.43 years and their current tenure was 4.48 years. The respondents can be argued to be highly educated. 
$54 \%$ of the respondents were holding bachelor degree and $43 \%$ of them have postgraduate degree, and the remaining $3 \%$ were high school graduates. Finally, although respondents' sector varies, the majority of them were from sales, banking and IT sectors.

\section{Measures}

Social and Economic Exchange Scale. Social and Economic Exchange relationship of participants with their organizations was measured by a total of 17 items. To measure the social and economic exchange relationship, Social and Economic Exchange Scale (SEES), which has been developed by Shore, Tetrick, Lynch \& Barksdale (2006), was used. Originally, the scale was composed of the two sub-dimensions; social exchange (e.g., "My organization has made a significant investment in me.") and economic exchange (e.g., "My relationship with my organization is strictly an economic one - I work and they pay me."). The Cronbach alpha value of the scale was found to be .87 in Shore et al.'s (2006) studies. The 17 items were used on a 6 point Likert-type ( $1=$ totally disagree, and $6=$ totally agree).

Organizational Commitment Scale. Meyer, Allen \& Gellatly's (1990) “Organizational Commitment Scale (OCS)", which has 24 items, was used to measure the commitment to organization levels of the employees in the workplace. However, 15 items were used in the present study because of proposed hypotheses. 7 items of the scale measure the affective commitment levels of the employees, whereas the other 8 items measure the continuance commitment levels of the employees. The Turkish translation was done by Wasti (2000) and the Cronbach alpha values of.79 for affective commitment levels of employees and .60 for continuance commitment levels of employees in their study. Additionally, Meyer and Allen' (2015) OC scale had a Cronbach alpha value of .83 for affective commitment dimension and .63 for continuance commitment dimension in a study of Başol and Yalçın (2009). The sample items for the scale are as follows: "I would be very happy to spend the rest of my career with this organization" (from the affective commitment scale); "I feel that I have very few options to consider leaving this organization" (from the continuance commitment scale).

\section{Results}

\section{Factor Analysis and Reliability of the Scales}

The factor structures of the scales were evaluated using factor analysis and reliability testing. Initially, in order to assess two instruments of research, it was analyzed the Kaiser-Meyer-Olkin (KMO) measure of sampling adequacy. Results showed that the KMO values of scales was at least .743, above the recommended value of .600 and Bartlett's test of sphericity was significant ( $p$ value $=.000)$. In SEES, when examined the economic exchange factor loadings, it was found that one item of scale was problematic because of its low factor loading. After removing this item (I only want to do more for my organization when I see that they will do more for me), an improved fit was achieved. Similarly, one item of affective commitment factor loading was low and therefore, the item was eliminated from scale (I enjoy discussing about my organization with people outside it). Afterwards, it was used Cronbach's Alpha statistic so as to measure internal consistency (reliability). Results confirmed that all the scales and items of scales was greater than 0.80 . In this perspective, the results of the factor and reliability analysis are as in Table 1 below.

Table 1. The summary statistics of survey $(N=186)$

\begin{tabular}{lcccc}
\hline Factor & Number of items & KMO & Cronbach's Alpha( $\alpha)$ & P value \\
\hline Economic Exchange & 7 & .781 & .840 & .000 \\
Social Exchange & 9 & .734 & .880 & .000 \\
Affective Commitment & 7 & .853 & .940 & .000 \\
Continuous Commitment & 8 & .743 & .810 & .000 \\
\hline
\end{tabular}

Correlations between Social and Economic Exchange and Sub-dimensions of Organizational Commitment

In order to test the hypotheses, first of all, Pearson's correlation analysis was conducted. In this context, Table 2 reports the means, standard deviations and correlations of all variables. In general, results show that there were low to moderate significant correlations among all variables. Firstly, "social exchange" had moderate positive significant relationship with $\mathrm{AC}(\mathrm{r}=0,57 ; \mathrm{p}<.01)$ and it had low positive significant relationship with CC. $(r=0,20 ; p<.05)$. The, "economic exchange" had moderate negative significant relationship with AC $(r=$ 
$-, 55 ; \mathrm{p}<.01)$ and it had low positive relationship with $\mathrm{CC}(\mathrm{r}=.11 ; \mathrm{p}<.01)$. The correlations indicated that especially the existence of social exchange is likely to increase employees' perceived AC while the existence of economic exchange is likely to decrease employees' perceived AC.

Table 2. Means, Standard Deviations, Correlations of All V ariables

\begin{tabular}{|c|c|c|c|c|c|c|c|c|c|c|c|}
\hline & Mean & $S D$ & 1 & 2 & 3 & 4 & 5 & 6 & 7 & 8 & 9 \\
\hline 1. Age & 28.31 & 4.96 & - & & & & & & & & \\
\hline 2. Educational Lev. & - & - & -.08 & - & & & & & & & \\
\hline 3. Total Tenure & 6.53 & 5.45 & $.55^{* *}$ & $-.55^{* *}$ & - & & & & & & \\
\hline 4. Current Tenure & 4.42 & 4.73 & $.36^{* *}$ & $-.45^{* *}$ & $.76^{* *}$ & - & & & & & \\
\hline 5. Social Exc. & 3.80 & .90 & -.03 & -.14 & .04 & $.36^{* *}$ & - & & & & \\
\hline 6. EconomicExc & 3.67 & 1.10 & .17 & .13 & -.09 & .05 & .00 & - & & & \\
\hline 7. AffectiveCom & 3.30 & 1.15 & -.00 & $-.42^{* *}$ & $.27^{*}$ & $.33^{*}$ & $.57^{* *}$ & $-.55^{* *}$ & - & & \\
\hline $\begin{array}{l}\text { 8. Continuance } \\
\text { Com. }\end{array}$ & 4.01 & .98 & .15 & $-.03 * *$ & -.04 & $.26^{*}$ & $.20^{*}$ & $.11 * *$ & .16 & -.07 & - \\
\hline
\end{tabular}

$N=186 ;{ }^{*} \mathrm{p}<.05 ; * * \mathrm{p}<.01$

\section{Regression Analyses on Sub-dimensions of Organizational Commitment}

Hierarchical regression analyses were applied (see Table 3) so as to examine the power of social and economic exchange in predicting the AC and CC. As three demographic variables, sex, age, and level of education were entered in the first step in these analyses; total tenure and current tenure were entered in the second step in order to statistically control the effect of these variable. The social and economic exchanges were entered in the last step.

Tablo 3. Summary of Hierarchical Regression Analyses for Social and Economic Exchange Predicting Affective and Continuance Commitment

\begin{tabular}{|c|c|c|}
\hline Independent variables & $\begin{array}{c}\text { AC } \\
B \\
\end{array}$ & $\begin{array}{c}C C \\
B \\
\end{array}$ \\
\hline \multicolumn{3}{|l|}{ Step 1.} \\
\hline Age & -.19 & $-.52^{* *}$ \\
\hline Sex & $.63^{* * *}$ & $1.55^{* * *}$ \\
\hline Education-Level & $.52^{* *}$ & $1.43^{* * *}$ \\
\hline $\mathrm{F}$ & 8.26 & 5.98 \\
\hline $\mathrm{R}^{2}$ & .29 & .22 \\
\hline Adjusted $\mathrm{R}^{2}$ & .25 & .19 \\
\hline \multicolumn{3}{|l|}{ Dependent variables: $A C$ and $C C$} \\
\hline \multicolumn{3}{|l|}{ Step 2.} \\
\hline Total Tenure & $.34^{* *}$ & .29 \\
\hline Current Tenure & $.18^{*}$ & $.61^{* * *}$ \\
\hline $\mathrm{F}$ & 20.51 & 38.82 \\
\hline $\mathrm{R}^{2}$ & .58 & .66 \\
\hline Adjusted $\mathrm{R}^{2}$ & .54 & .63 \\
\hline \multicolumn{3}{|l|}{ Dependent variables: $A C$ and $C C$} \\
\hline \multicolumn{3}{|l|}{ Step 3.} \\
\hline Social Exc. & $.46^{* * *}$ & .01 \\
\hline Economic Exc. & $-.44^{* * *}$ & $.34^{* *}$ \\
\hline $\mathrm{F}$ & 48.46 & 7.90 \\
\hline $\mathrm{R}^{2}$ & .84 & .73 \\
\hline Adjusted $\mathrm{R}^{2}$ & .82 & .70 \\
\hline Dependent variables: $A C$ and $C C$ & & \\
\hline
\end{tabular}

${ }^{*} \mathrm{p}<.05,{ }^{* *} \mathrm{p}<.01,{ }^{* * *} \mathrm{p}<.001$

At Step 1, the results indicated that the demographic variables could explain an important portion of the variability among both $\mathrm{AC}(\mathrm{R} 2=.29)$ and $\mathrm{CC}(\mathrm{R} 2=.22)$. Among the regression coefficients sex $(\beta=$ $.63 ; \mathrm{p}<.01)$ and education level $(\beta=.52 ; \mathrm{p}<.05)$ were significant among AC. Among CC, age $(\beta=-.52$; $\mathrm{p}<.05)$, sex $(\beta=1.55 ; \mathrm{p}<.05)$ and educational level $(\beta=1.43 ; \mathrm{p}<.05)$. The results of hierarchical regression analysis revealed that total and current tenure could explain extra variability among AC (R2 = 
$.58)$ and $\mathrm{CC}(\mathrm{R} 2=.66)$. Although the coefficients were significant in the second step they became nonsignificant in the third step. At step 3, the results of hierarchical regression analysis showed that $\mathrm{R}$ was significantly different from zero, $\mathrm{F}(7,136)=43.87, \mathrm{p}<.001)$. The model could explain the $84 \%$ of the variability among AC $(\mathrm{R} 2=.84)$. Among the coefficients both the social exchange $(\beta=.46, \mathrm{p}<.001)$ and economic exchange $(\beta=-.44, \mathrm{p}<.001)$ were significant. By looking at the coefficients it can be concluded that an unit increase in social exchange score increases AC (H1.1) and an unit increase in economic exchange score decreases AC (H2.1).

According to hierarchical regression analysis, $\mathrm{R}$ was again significantly different from zero $\mathrm{F}(7,136)$ $=22.90, \mathrm{p}<.001$ for CC. The model could explain the 73\% of the variability among CC $(\mathrm{R} 2=.73)$. Among the coefficients only the economic exchange $(\beta=.34, \mathrm{p}<.01)$ was significant for CC. By looking at the coefficients it can be concluded that an increase in economic exchange score increases CC (H2.2). In addition, among the coefficients the social exchange $(\beta=.01, \mathrm{p}<.01)$ was significant for CC. However, this statistical value is rather low. Operationally, by looking at the coefficients it can be said that an increase in social exchange score increases CC but, the effect of this changing is too low to be felt (H1.2).

\section{Conclusion, Discussion and Suggestion}

This study concentrated on the impact of employees' perceptions of social and economic exchanges on their commitment towards their organizations. It is well known that there are so many dynamics that affect employees at organizational level. Therefore, to understand relationships based on employee has gain wide importance for organization. In this context, the present study was conducted on employees of private sector in Turkey.

In the present study, firstly, the concept of social\&economic exchange and dimesions of organizational commitment. Afterwards, importance and hypotheses of the research were discussed. Secondly, methodology of the research is discussed in detail; factor \& reliability analysis and correlation \& regression analysis. In order to evaluate social\&economic exchange at organizations, it was used Social and Economic Exchange Scale (SEES), which has been developed by Shore, et.al., (2006). To test of levels of affective \& continuance commitment levels of the employees, it was used Meyer, Allen \& Gellatly's (1990) "Organizational Commitment Scale" (OCS). The first finding related with the hypotheses of the study was that social exchange had a positive effect on affective commitment. The mean score of social exchange scale was 3.80 , which represented the moderate social exchange at organizations. Also, social exchange had significant incremental explanatory power over affective commitment $(\beta=0.46, \mathrm{p}=.000)$. It means that, as employees share intangible resources with other employees in their organization, they feel more affective commitment towards organization. In particular, when they can satisfy their social needs through a social exchange relationship, they demonstrate higher levels of affective commitment. Thus, the result supported first hypothesis (H1.1). This result is consistent with Eisenberger, et. al.'s study (1986). At the same time, the result has been also confirmed by recent studies (Yiğit, 2016; Yu, Mai, Tsai \& Dai, 2018).

The second related with the hypotheses of the study was that social exchange had a positive effect on continuance commitment. Similarly, as based on the social exchange mean score, the score had ultra-low explanatory power over continuance commitment $(\beta=0.01, \mathrm{p}=.000)$. Thus, in part, the result supported second hypothesis (H1.2). The third hypothesis was that economic exchange had a negative effect on affective commitment. The mean score of economic exchange scale was 3.67, which represented the moderate economic exchange at organizations. Also, economic exchange had significant incremental explanatory power over affective commitment $(\beta=-0.44, p=.000)$. It means that, if employees have a strong tendency to view their relationship with their organizations as a purely economic transaction, they are unlikely to show affective commitment. Thus, the result supported third hypothesis (H2.1). Finally, fourth hypothesis was that economic exchange had a positive effect on continuance commitment. Similarly, as based on the economic exchange mean score, economic exchange had significant incremental explanatory power over continuance commitment $(\beta=0.34, \mathrm{p}=.000)$. It means the employees who are economic exchange-oriented may only show moderate levels of continuance commitment. Thus, the result supported fourth hypothesis (H2.2). This result is consistent with Shore and Tetrick, 2006' s study (1986). According to their findings, continuance commitment was positively related to economic exchange (Shore and Tetrick, 2006). 
Moreover, in literature review chapter, the field study was finalized; the descriptive statistics were investigated and tested the hypotheses successfully. According to the results of the hypothesis, most of the hypotheses were supported positively. It is well known that quality of employee-organization relationship is determinant factor for promoting positive psychology and behavior (Tsui, Pearce, Porter, \& Tripoli, 1997). For this reason, to understand the association between give \& take mechanism with tangible or intangible outcomes and employee's commitment toward organization has gained wide importance in recent years for effectiveness. In this context, the sample of this study included employees working in various private sectors without differentiating between sectors.

Firstly, it have been hypothesized that social exchange, which is characterized by feelings of gratitude, trust an obligation to reciprocate, would be correlated with all subdimensions of organizational commitment. Specifically, it was expected that social exchange would have stronger relation with affective commitment, since it is associated with bonding that includes more socio-emotional responses, such as attachment, involvement and embeddedness. Not surprisingly, results have revealed a moderate correlation between social exchange and affective commitment. As it was mentioned in previous chapters of this study, social exchange is not merely about exhange of labor and time in return for money and other benefits. It also includes emotional exchange and sentimental investment between employees and the organizations. Similarly, affective commitment is characterized by emotional involvement and it motivates employees to preserve the bonding with their organizations. Moreover, trust is an important compenent of social exchange process in the relationship among parties. At this point, trust may be an effective predictor of employees' positive attitudes and behaviors such as affective commitment. Thanks to high trust level within organization, it will be provided to maintain well-qualified long-term relationship. For this reason, it can be argued that the employees who could develop social exchange relationship with their organizations may have felt the obligation to reciprocate with their organizations through their commitment (Cronpanzano, \& Mitchell, 2005). Besides the correlation between social exchange and affective commitment, there is an effect of social exchange on affective commitment. It means that one unit increase in social exchange will increase affective commitment of employees towards to organization at the same rate. That is, increase in social exchange score increases AC. It is possible to express that the social exchange relationships among employees and their co-workers increase the affective commitment towards organization. Thus, this interaction may lead to other positive and desirable outcomes in organization such as job involvement or workplace wellbeing. In brief, the result supported first hypothesis (H1.1).

Apart from affective commitment, it is hypothesized that continuance commitment would be correlated with social exchange. Regarding its association with social exchange, it was argued that employees who have developed a social exchange relationship with their organizations would have no reason to keep the status quo. In fact, they might be afraid of losing their positions in their organizations where they have emotional attachment. Expectedly, results have revealed significant, but relatively weak association between social exchange and continuance commitment. Therefore, it can be argued that individuals who have social exchange relationships with their organizations have no incentive to lose their jobs in their organizations where they have socio-emotional connection. According to result of regression analysis, this effect is just as weak as the correlation result. It means that increase in social exchange score increases CC at least. Furthermore, this result confirmed that social exchange contributes such loyalty commitment style. Employees care about intangible values and outcomes as well as tangible ones. Such that, although employees are not financially satisfied, they may desire to work in a organizational environment with happy and healthy relationships. Thus, the result supported second hypothesis (H1.2).

In this study, it was also investigated the relationship between economic exchange and affective and continuous commitment. It was hypothesized that economic exchange would be negatively correlated with affective commitment, which is associated with feelings of emotional bonding. Because of natura of economic exchange (short-term \& well-defined obligations and close-ended relationships) it can not be metioned psychological connections between organization and employees. At the same time, it is wellknown that such exchange relationships include narrow financial obligations (e.g., pay and benefits) rather than long-term investments (e.g., employment security or career planning). In this circumtances, natural and expected outcomes by employees cannot be related to socio emotional outcomes (Song et al, 2009). Expected from this study, results have revealed a moderately negative correlation between economic exchange and affective commitment. For this reason, it can be argued that employees who are dominantly economic exchange-oriented show little, if any, emotional attachment towards their organizations. In 
addition, regression result show that there is negative effect of economic exchange on affective commitment. Thus, the result supported third hypothesis (H2.1). In brief, one unit decrease in economic exchange will increase affective commitment of employees towards to organization at the same rate. In other words, decrease in economic exchange score increases AC.

Regarding hypotheses of the study, it is finally argued that economic exchange would have positive association with continuance commitment. Thse results didn't confirm this hypotheses. Firstly, the correlation between economic exchange and continuance commitment was moderate. The main reason for a moderate correlation might be the fact that participants of this study were marital status and having children. Secondly, the effect of economomic exchange on continuos commitment is moderate positively. The main reason may be work alternatives of employees for the present study. Here, employees have belief that their salary and fringe benefits will improve even if they move to another organisation. Thus, the result supported fourth hypothesis (H2.1). In brief, one unit decrease in economic exchange will decrease continuance commitment of employees towards to organization at the same rate. Namely, decrease in economic exchange score decreases CC.

However, this study includes a set of limitations. Firstly, the questionnaire survey was carried out among the employees working in private sector in Istanbul / Turkey. Therefore, the findings related to study may not be valid for different type of organizations. Additionally, as mentioned before, this study was carried out in Istanbul, for this reason results do not cover other cities or countries. Instead, it is useful to examine organizational dynamics of this study on sectorial or occupational settings so that the findings can be determined across the only group of population of Turkey. Future studies can be conducted on organizational level and can focus on one unique sector. Additionally, the effects of national or organizational culture and perception of organizational climate should not be overlooked because the expectations of employees from social and economic exchange differ from culture to culture or from organization to organization. Besides, the sample size of the current research is not appropriate so as to reach a general opinion. Moreover, quantitative research method was used for the present study. However, as might be expected, this method can be affected by social desirability response bias. For this reason, qualitative data research could be incorporated to study in order to precise results by decreasing bias. Additionally, in the current study context, it can be suggested that the mediator or moderating role of variables could be examined in future studies. Besides, the effect of social \& economic reciprocity on the normative commitment dimension has not been measured for this research. In the upcoming research, this dimension can be involved in the model together with mediator or moderator variables. Finally, this research was conducted only on the private sector employees who work in Istanbul. This relationship can be also examined in public institutions that may vary in terms of organizational culture.

As a concluding remark, the present study may make a contribution to the organizational behavior literature discussion in terms of individual dynamics and organizational outcomes.

\section{Ethical Declaration}

In the writing process of the study titled "The Social \& Economic Exchange Relationships in The Context of Organizational Commitment", there were followed the scientific, ethical and the citation rules; was not made any falsification on the collected data and this study was not sent to any other academic media for evaluation.

\section{References}

Angle, H. L., \& Perry, J. L. (1981). An empirical assessment of organizational commitment and organizational effectiveness. Administrative Science Quarterly, 1-14.

Angle, H. L., \& Perry, J. L. (1983). Organizational commitment: Individual and organizational influences. Work and Occupations, 10(2), 123-146.

Annakili, P., \& Jayam, R. (2019). How to increase organizational commitment through employees participation. Eurasian Journal of Analytical Chemistry, 13.

Anttila, E. (2015). Components of organizational commitment-A case study consisting managers from Finnish industrial company (Master's thesis).

Berberoglu, A. (2015). Organizational commitment and perceived organizational performance among health care professionals: Empirical evidence from a private Hospital in Northern Cyprus. Journal of Economics and Behavioral Studies, 7(1), 64-71.

Blau, P. M. (1968). Social exchange. International encyclopedia of the social sciences, 7, 452-457. Citizenship 
behaviors: a critical review of the theoretical and empirical literature and suggestions for future research. Journal of Management, 26, 513-563.

Buchanan, B. (1974). Building organizational commitment: The socialization of managers in work organizations. Administrative Science Quarterly, 533-546.

Cheng, B. S., Jiang, D. Y., \& Riley, J. H. (2003). Organizational commitment, supervisory commitment, and employee outcomes in the Chinese context: proximal hypothesis or global hypothesis?. Journal of Organizational Behavior: The International Journal of Industrial, Occupational and Organizational Psychology and Behavior, 24(3), 313-334.

Cohen, A. (2014). Organisational commitment research: Past, present and future. In Areas of Vocational Education Research (pp. 261-274). Springer, Berlin, Heidelberg..

Cole, M., Schaninger, W. Jr., \& Harris, S, (2002). The workplace social exchange network: A multilevel, conceptual examination. Group \& Organization Management, 27(1), 142-168.

Cropanzano, R., \& Mitchell, M. S. (2005). Social exchange theory: An interdisciplinary review. Journal of Management, 31(6), 874-900.

Dabir, A. R., \& Azarpira, M. (2017). Organizational commitment and its impact on employees' individual interactions. International Journal of Human Capital in Urban Management, 2(1), 49-56.

Eaton, S. C. (2003). If you can use them: Flexibility policies, organizational commitment, and perceived performance. Industrial Relations: A Journal of Economy and Society, 42(2), 145-167.

Eisenberger, R., Huntington, R., Hutchison, S., \& Sowa, D. (1986). Perceived organizational support. Journal of Applied Psychology, 71, 500-507.

Emerson, R. M. (1962). Power-dependence relations. American Sociological Review, 27, 31-41.

Emerson, R. M. (1972). Exchange theory. In J. Berger, M. Zelditch, \& B. Anderson (Eds.), Sociological theories in progress (Parts 1 \& 2), 2, Boston: Houghton MifHin.

Emerson, R. M. (1976). Social exchange theory. Annual Review of Sociology, 2(1), 335-362.

Ertürk, E. (2014). Sosyal mübadele teorisi bağlamında güc mesafesi ve örgütsel adalet algzlamalarmın örgütsel vatandaşlı davranışlar üzerindeki etkisi, (Doktora Tezi), Selçuk Üniversitesi Sosyal Bilimler Enstitüsü, Konya.

Foa, U. G., \& Foa, E. B. (1980). Resource theory: Interpersonal behavior as exchange. In K. J. Gergen \& M. S. Greenberg \& R. H. Willis (Eds.), Social exchange: Advances in theory and research. New York: Plenum.

Hackett, R. D., Farh, J., Song, L. J., \& Lapierre, L. M. (2003). LMX and Organizational Citizenship Behavior: Examining the Links within and Across Western and Chinese Samples. G. B. Graen (Ed.). Dealing with Diversity: A Volume in: LMX Leadership: The Series, (219-264). Greenwich, CT: Information Age Publising.

Hanaysha, J. (2016). Testing the effects of employee engagement, work environment, and organizational learning on organizational commitment. Procedia-Social and Behavioral Sciences, 229(8), 289-297.

Hom, P. W., Tsui, A. S., Wu, J. B., Lee, T. W., Zhang, A. Y., Fu, P. P., and Li, L. (2009). Explaining employment relationships with social exchange and job embeddedness. Journal of Applied Psychology, 94, 277-297.

Homans, G. (1961). Social Behaviour: Its Elementary Forms. London: Routledge and Kegan Paul.

Köksal, O. (2012). Sosyal değişim teorisi çerçevesinde güven ve algılanan aidiyet durumunun örgütsel vatandaşlı davranışı ve saldırgan davranıslar üzerine etkisi, (Doktora Tezi). Erciyes Üniversitesi Sosyal Bilimler Üniversitesi, Kayseri.

Liu, X., \& Deng, J. (2011). Development of organizational commitment based on the social exchange theory. International Conference Management and Service Science (MASS), Thailand: Bangkok.

Lyons, S. T., Duxbury, L. E., \& Higgins, C. A. (2006). A comparison of the values and commitment of private sector, public sector, and parapublic sector employees. Public Administration Review, 66 (4), 605- 618.

Malinowski, B. (1922). Argonauts of the Western Pacific. London: Routledge and Kegan Paul.

Markovits, Y., Davis, A. J., \& Van Dick, R. (2007). Organizational commitment profiles and job satisfaction among Greek private and public sector employees. International Journal of Cross Cultural Management, 7(1), 77-99.

Maxwell, J. C. (1999). The 21 indispensable qualities of a leader: Becoming the person others will want to follow. Nashville: Thomas Nelson Publishers.

McGee, G. W., \& Ford, R. C. (1987). Two (or more?) dimensions of organizational commitment: Reexamination of the affective and continuance commitment scales. Journal of applied psychology, 72(4), 638.

Meyer J. P., Allen, N. J., and Smith, C. (1993). Commitment to organizations and occupations: extension and test of a three-component conceptualization. Journal of Applied Psychology, 78, 538-551.

Meyer, J. P., \& Allen, N. J. (1991). A three-component conceptualization of organizational commitment. Human Resource Management Review, 1(1), 61-89.

Meyer, J. P., Allen, N. J., \& Gellatly, I. R. (1990). Affective and continuance commitment to the organization: Evaluation of measures and analysis of concurrent and time-lagged relations. Journal of Applied Psychology, 75(6), 710.

Molm, L. D. (2003). Theoretical comparisons of forms of exchange. Sociological Theory, 21, 1-17.

Podsakoff, P. M., MacKenzie, S. B., Paine, J. B., \& Bachrach, D. G. (2000). Organizational citizenship behaviors: A critical review of the theoretical and empirical literature and suggestions for future research. Journal of Management, 26(3), 513-563.

Radosavljević, Ž., Ćilerdžić, V., \& Dragić, M. (2017). Employee organizational commitment. International Review, (1-2), $18-26$.

Randall, D. M., Fedor, D. B., \& Longenecker, C. O. (1990). The behavioral expression of organizational commitment. Journal of Vocational Behavior, 36(2), 210-224.

Reichers, A. P. (1985). A review and reconceptualization of organizational commitennt. Academy of Management Review, 
$10,465-476$.

Sager, J. K., \& Johnston, M. W. (1989). Antecedents and outcomes of organizational commitment: A study of salespeople. Journal of Personal Selling \& Sales Management, 9(1), 30-41.

Shore, L. M., \& Wayne, S. J. (1993). Commitment and employee behavior: Comparison of affective commitment and continuance commitment with perceived organizational support. Journal of Applied Psychology, 78(5), 774.

Shore, L. M., Bommer, W. H., Rao, A. N., \& Seo, J. (2009). Social and economic exchange in the employeeorganization relationship: The moderating role of reciprocation wariness. Journal of Managerial Psychology, 24(8), 701-721.

Shore, L. M., Tetrick, L. E., Lynch, P., \& Barksdale, K. (2006). Social and economic exchange: Construct development and validation. Journal of Applied Social Psychology, 36(4), 837-867.

Shore, L., Coyle-Shapiro, J., Chen, X., \& Tetrick, L. (2009). Social exchange in work settings: Content, process, and mixed models. Management and Organization Review, 5(3), 289-302.

Shore, L.M., Tetrick, L.E., Lynch, P., \& Barksdale, K. (2006). Social and economic exchange, construct development and validation. Journal of Applied Social Psychology, 36, 837-67.

Song, J., Tsui, A. S., \& Law, K. S. (2009). Unpacking employee responses to organizational exchange mechanisms: The role of social and economic exchange perceptions. Journal of Management, 35(1), 56- 93.

Steers, R. M. (1977). Antecedents and outcomes of organizational commitment. Administrative Science Quarterly, 22, 46-56.

Thibault, J., \& Kelley, H. H. (1959). Evaluation of the Dyad. The Social Psychology of Groups. New Brunswick, New Jersey, Transaction Publishers.

Top, M., Akdere, M., \& Tarcan, M. (2015). Examining transformational leadership, job satisfaction, organizational commitment and organizational trust in Turkish hospitals: public servants versus private sector employees. The International Journal of Human Resource Management, 26(9), 1259-1282.

Tsui, A. S., Pearce, J. L., Porter, L. W., \& Tripoli, A. M. (1997). Alternative approaches to the employee-organization relationship: does investment in employees pay off? Academy of Management Journal, 40(5), 1089-1121.

Tsui, A. S., Pearce, J. L., Porter, L.W., \& Tripoli, A. M. (1997). Alternative approaches to the employee-organization relationship: Does investment in employees pay off? Academy of Management Journal, 40, 1089-1121.

Wasti, S. A. (2005). Commitment profiles: Combinations of organizational commitment forms and job outcomes. Journal of Vocational behavior, 67(2), 290-308.

Yiğit, İ. (2016). The effect of organizational commitment on the social exchange and organizational socialization: A study in research and practice hospital of Kocaeli University. Kafkes Üniversitesi İktisadi ve İdari Bilimler Fakültesi Dergisi, 7(12), 25-50.

Yu, M. C., Mai, Q., Tsai, S. B., \& Dai, Y. (2018). An empirical study on the organizational trust, employeeorganization relationship and innovative behavior from the integrated perspective of social exchange and organizational sustainability. Sustainability, 10(3), 864.

Zhu, Y. (2012). Social exchange relationship, economic exchange relationship, in-role behavior: The mediating effects of job satisfaction. Asian Social Science, 8(8), 194-199.

\section{TÜRKÇE GENİ̧̧ ÖZET}

Günümüzde hızla değişen modern dünya düzeninde bireylerin yaşantılarının büyük bir bölümü iş yerinde geçmektedir. Tipkı özel yaşamında olduğu kadar iş yaşamında da bireyin zamanını mutlu ve kaliteli geçirmesi bireysel mutluluk düzeyi için oldukça önem arz etmektedir. Akademisyenlerin sıklıkla üzerinde durduğu iş yaşam dengesi, özünde yaşam doyumuna atıfta bulunurken bu dengeyi sağlamış olmak mutlu bir insan olmanın temel noktalarından biri olmuştur. Bu kapsamda düşünüldüğünde iş yerinde meydana gelen bir takım dinamikler, çalışanların hem bireysel hem de örgütsel düzeyde duygu, tutum ve davranışlarını etkilemektedir. Duygu ve tutumların yön verdiği davranışlar ise çalışanların ve örgütlerin akıbetini belirlemektedir. Bu çalışmada, çalışanların birbirleri ve örgütleri ile takas ilişkisinin örgüte olan bağlılıklarını ne düzeyde etkilediği açıklanmaya çalışılmıştır. Bu kapsamda, öncelikle sosyal ve ekonomik değişim ilişkileri ile örgütsel bağlllı̆̆ın iki alt boyutu (duygusal bağlılık ve devam bağlllğ̆1) hakkında mevcut literatür incelemesi yapılmış ve daha sonra kavramlar arasında var olduğu düşünülen ilişkinin yönü ve derecesi incelenmiştir. Özel yaşamda olduğu gibi kurumsal yaşamda da ilişkilerin ana motivasyonu ilişkinin yapısına göre karşı taraftan soyut ya da somut geri dönüş almaktır. Bu noktada örgütlerde de değişim ilişkisinin altında yatan norm sosyal veya ekonomik çıktılar olarak karşılıklılık ilkesine dayanmaktadır (Zhu, 2012). Öte yandan, çalışanların örgüt içindeki değişim ilişkisine yönelik algılanı, örgütsel öncüllerin ve çıktıların önemli bir belirleyicisi olmaktadır. Örgütlerde yaşanılan değişim ilişkileri de çalışanların değişim algisna göre şekillenmekte ve en nihayetinde farklı tutum ve davranışlara sebebiyet vermektedir. Çalışmalardan elde edilen bulgular bu tür muamelelerin ya nispeten uzun vadede güven gibi bir sosyal değişim ilişkisine ya da kısa vadede ekonomik kazanımlı bir değişim ilişkisine yol açabileceğini göstermektedir (Shore, vd. 2006; Song, vd. 2006). Bu nedenle sosyal ve ekonomik değişim ilişkisinin 
çalışanın örgütsel bağlllığı üzerindeki etkisini anlamak örgütler için önemli olacaktır.

Alanyazında değişim ilişkilerine dair geniş bir teorik arka plan bulunmaktadır. Sosyal değişim teorisini geliştiren Blau (1964), değişim ilişkilerinin örgütler için en etkili örgütsel dinamiklerden biri olduğunu belirtmiş ve çalışanlar ile örgütleri arasında gerçekleşen soyut ve somut alışverişte tarafların denge beklentisinin olduğunu ifade etmiştir. Bu noktada Molm (2003) ise çalışanların verilenler ile karşıllı̆̆ında elde edilenler arasında herhangi bir uyuşmazlık algılamaları durumunda alışveriş ilişkisindeki bu tutarsızlı̆̆ ortadan kaldırma çabalarınn olacağını savunmaktadır (Molm, 2003). Bu açıdan, çalışanlar ve örgütleri arasındaki ilişki, hem sosyal hem de ekonomik bileşenleri olan bir takas olarak tanımlanabilir. Nitekim bir örgüt içindeki değişim ilişkileri, bu eylemlerin benzer şekilde iade edileceği beklentisi ile gerçekleştirilen gönüllü eylemlerle belirlenmektedir (Köksal, 2012). Sosyal ve ekonomik değişim olarak gruplandırılan bu beklentilerde sosyal değişim daha karmaşık yükümlülüklere dayanır. Sosyal paylaşımda, çalışanlar yalnızca somut varlıklarını arttırmayı amaçlamazlar. Sosyal değişim taraflar arasında tatmin edici bir ilişkiyi de gerektirir ve bu ilişki, tarafların kısa sürede aldığ1 şeylerle ilgili değildir (Song, Tsui ve Law, 2009). Ekonomik değişim ise nispeten kısa vadeli ve finansal odaklı ilişkileri içeren alışveriş olarak tanımlanır. Özetle, ekonomik bir değiş tokuşta etkileşimler, tarafları birbirine bağlayan değerlerden farklı değerlere sahip olan mal ve hizmetlerin değişimine atıfta bulunur (Shore, Bommer, Rao \& Seo, 2009).

Bu çalısmanın bir diğer değişkeni olan örgütsel bağlllık ise örgütler için önemli olan bir diğer konudur ve örgütlerin işlerini en iyi şekilde tamamlamalarını sağlar. Örgütsel bağlllık yoğun bir özveri gerektirir ve çalşanların örgütsel değerler, amaçlar ve bu amaçlara ulaşma isteği ile ilgili inancını temsil eder (Maxwell, 1999). Genel anlamda, örgütsel bağlllık, çalışanın belirli bir kuruluşla özdeşleşmesi ve bulunduğu bu kuruluşa kendini psikolojik olarak dahil etmesiyle ilgilidir (Lyons, Duxbury \& Higgins, 2006). Meyer ve Allen (1991) da bir kuruluşa olan bağlllı̆̆n psikolojik bir durum olduğunu ifade etmiştir. Aynı zamanda Meyer ve Allen (1991) çalışanların çalıştıkları kuruluş hakkında neler hissettiğini açıklayan örgütsel bağlllığın duygusal, devam ve normatif olmak üzere üç ayrı bileşene sahip olduğunu belirtmiştir. Duygusal bağılık, bir çalışanın işi ile olan duygusal bağıdır. Çalışanın, örgütle olan duygusal bağına, kimliğine ve katılımına atıfta bulunur. Devam bağllı̆̆̆, çalışanın şu anki işini kaybetme korkusuyla ilişkilidir ve örgütten ayrılma maliyetinin farkındalığına işaret eder. Son olarak, normatif bağlılık mevcut işte kalma yükümlülüğüne dair sorumluluk duygusudur (Allen ve Meyer, 1991).

$\mathrm{Bu}$ noktadan hareketle, bu çalışmada sosyal ve ekonomik değişim ilişkilerinin çalışmanın bağımlı değişkenleri olan duygusal bağlllık ile devam bağlllı̆̆ üzerindeki etkisi incelenmiştir. Aynı zamanda, duygusal bağllığın çalışanın işi ile olan duygusal bağı olduğundan takas ilişkisinin finansal ve daha somut yönlerini vurgulayan ekonomik değişim ile açılanamayacağ 1 ön görülmüştür ve ekonomik değişimin duygusal bağlılık üzerinde negatif bir etkisinin olması beklenmektedir. Ancak, devam bağlllğında çalışan, bir kuruluştan ayrılma maliyetlerini ve kuruluşta kalmanın yararlarını göz önününde bulundurduğu için bu boyut üzerinde ekonomik değişimin pozitif etkisinin olması beklenmektedir.

Böylece, bu çalışmada, özel sektörde çalışan bireyler üzerinde yapılmış olan bir araştırma ile, sosyal ve ekonomik değişim ilişkilerinin duygusal bağlllık ve devam bağlllı̆̆ üzerindeki etkileri incelenmiştir. Araştırmanın evreni, Türkiye`de özel sektörde yer alan kurumlarda çalışanlardan oluşmaktadır. Araştırmanın örneklem grubunu ise İstanbul ilinde özel sektörde çalışan 189 çalışan oluşturmuştur.

Elde edilen veriler sosyal bilimlerde kullanılan istatistik paketi ile çeşitli analizlere tabi tutulmuştur. Uygulanan istatistiksel analizler, çalışmanın tüm hipotezlerin desteklendiğini göstermektedir. Buna göre, sosyal değişimin duygusal bağllık üzerinde $(\beta=.46, \mathrm{p}<.001)$ ve devam bağlllı̆̆1 üzerinde $(\beta=.01, \mathrm{p}<$ .01) anlamlı ve pozitif; ekonomik değişimin ise duygusal bağllık üzerinde anlamlı ve negatif $(\beta=-.44, p<$ $.001)$; devam bağlllığı üzerinde anlamlı ve pozitif $(\beta=.34, \mathrm{p}<.01)$ etkilerinin olduğu tespit edilmiştir.

Sonuç olarak, bu çalışma ile çalışanların kurumlarına duygusal açıdan bir bağlılık hissetmesi ile devam bağlllığ1 gibi bir tutum sergilemesinin öncüllerinin neler olabileceği tartışllmış ve sosyal ve ekonomik değişimin bu duygu ve tutum üzerindeki önemi vurgulanmışırı.

Anabtar Kelimeler: Sosyal değişim, Ekonomik değişim, Duygusal bağlllık, Devam bağlllığı. 